Directoraat-Generaal Milieubeheer 13-4-2001.

12. Pongratz $A$, Schwarzkopf $A$, Hahn $H$, Heesemann J, Karch $H$, Doll W. [The effect of the pipe material of the drinking water system on the frequency of Legionella in a hospital; in German]. Zentralbl Hyg Umweltmed 1994;195(5-6):483-8

13. Jansen PFC (ed). Duurzaam Bouwen. Nationaal pakket Woningbouw. Rotterdam, Stichting Bouwresearch, 1996. ISBN 905367-175-7

14. Snijders MCL. Indoor Air Quality and Physical Independence. An Innovative View on
Healthy Dwellings for Individuals with Chronic Lung Disease (PhD Thesis). Eindhoven: Eindhoven University of Technology; September 5, 2001. ISBN 906814-122-8

15. Steinert M, Ockert G, Luck C, Hacker J. Regrowth of Legionella pneumophila in a heat-disinfected plumbing system. Zentralbl Bakteriol 1998;288(3):331-42

16. Kool JL, Carpenter JC, Fields BS. Effect of monochloramine disinfection of municipal drinking water on risk of nosocomial Legionnaires' disease. Lancet 1999;353(9149):272-7

\title{
European Commission support
}

\author{
Jan A.M. Graafmans MSc \\ International Society for Gerontechnology, Kempenlaan 5, 3020 Herent, Belgium \\ e-mail: j.a.m.graafmans@tue.nl
}

\begin{abstract}
J.A.M Graafmans, European Commission support, Gerontechnology, 2001; 1(1):
68 - 70. The Directorates of the European Commission have a history of 20 years in programming research and technology development in so-called framework programs. Age-related programs addressed Technological Issues of relevance to the ageing population of Europe. At present the 'User-Friendly Information Society' and 'Quality of Life' are ongoing relevant programs. In the near future the 6th Framework may bring more focus on e-Accessibility.
\end{abstract}

Key words: cost, 6th framework, European Union

\section{THE PAST}

The European Union has a history of 20 years in programming research and technological development in the so-called framework programs.

Research and demonstration projects of a more applied nature were also funded through other Directorates, such as Employment, Social Affairs, and Industrial Relations, Transport, and Information Society. In the beginning Ageing and Technology did not appear on the research agenda, but could be found under Biomedical Technology and the Information and Communication Technology programs. As a consequence, the orientation was strongly focused on the medical field or on technology applications relat- ed to disabled persons. Ageing and the ageing population as separate issues emerged in the beginning of the 90 s.

The action 'Ageing and Technology' (COST A5 1991-1996) started immediately after the 1st Conference on Gerontechnology in Eindhoven, under the auspices of European Cooperation in Science and Technology. The leading idea of COST A5 was that the population of Europe is rapidly ageing, but needs, preferences and capabilities of older people had not received sufficient attention'. This is true for resources in research and technological development, as well as for the potential for technological interventions to enhance physiological capability and health status throughout life. 
The overall objective of COST A5 activities was to explore conditions for extended autonomy, independence, and activity for older people in a European comparative perspective. It led to conferences on such subjects as mobility, housing, health, design, and on gerontechnology education, all with useful conference reports. This essentially formed the basis for the International Society for Gerontechnology that started in 1997. General studies in which the network was instrumental were the JRC (Joint Research Centre)-study: 'The state of the art in ageing and technology'2, and in the ETAN (European Technology Assessment Network)-expert group on 'Ageing and Technology'3 .

Together with other initiatives such as EurolinkAge and the Design for Ageing Network (DAN), this has been instrumental in getting 'Ageing and Technology' on the agenda of the present 5th Framework Program (1998-2002) ${ }^{4}$.

\section{THE PRESENT}

Topics from the domain of gerontechnology are explicitly present in two out of four different programs in the 5th framework each with specific key actions. The programme 'Quality of life and Management of Living Resources' has the key action 'The Ageing Population'. The overriding goal of this key action is to promote quality of life and healthy ageing and independence in old age by preventing and treating age-related diseases and disability, and their societal consequences. A complementary objective is to reduce the need for long-term care and limit the constantly increasing costs of health-care systems. The key action 'Systems and Services for the Citizen' runs under the Programme 'User friendly Information Society'. This key action addresses the topics 'Health' and 'Persons with special needs'. In 'Health' the work covers new generation computerised clinical systems, advanced telemedicine services and health network applications to support health professionals, continuity of care and health service management, and intelligent systems allowing citizens to assume greater participation and responsibility for their own health. Both professional and personal health care systems are included.

In 'Persons with Special Needs', such as older people, the work addresses person/system interfaces and adaptive and assistive systems to overcome problems caused by environmental barriers and by physical or intellectual impairments. Additionally, intelligent systems and services are addressed to support autonomous living, social integration, and participation in the information society.

\section{THE FUTURE}

The 6th framework program (2002-2006) is under discussion ${ }^{5}$ and as far as older people is concerned the main focus is on 'Genomics and Biotechnology for Health', on 'Information Society Technologies', and on 'Social Exclusion'. Genomics will concentrate on genetics and biotechnology and slightly touch upon the ageing process. The IST paragraph mentions that the information society should be accessible for all people whatever their age or situation. So far, this has resulted in a discussion paper called 'eAccessibility for all', a publication prepared by the unit 'Persons with Special Needs, including the Disabled and the Elderly'.

Some preliminary conclusions of this discussion paper that might eventually lead to research funding in the future are:

1. e-Accessibility for all is a vision rather than a simple initiative and new product development should involve users at all stages and be combined with socio-economic studies.

2. e-Accessibility is a multidisciplinary research field that requires technical, legal, and social expertise and development efforts should also be complemented with appropriate awareness and educational activities. 
3. e-Accessibility becomes specially important in some emerging areas such as, (a) cognitive impairments due to its significance for elderly people, (b) systems to consider the growing number of informal carers, (c) systems to address the real issues of hearing impairment, (d) Tracing/tracking of people mainly with mental disabilities and (e) enabling the full use of mobile telecommunication systems.

However, discussion on the final form of the 6 th framework is ongoing. Only at the beginning of 2002, it will be fully clear where gerontechnology can be positioned in this program. Differently from the past, the various Directorate-Generals will have the opportunity to themselves initiating research themes during the period covered by the program, thus addressing newly emerging issues immediately.

\section{References}

1. Taipale V, Reinisch H (Eds.). Ageing and Technology: 1991-1995. COST Programme Office. European Commission, Brussels.

2. Ageing and Technology - State of the art. EUR 17285. European Commission. Institute for Prospective Technological Studies - JRC Seville, June 1997.

3. ETAN Working Paper. The ageing population and technology: challenges and opportunities. ETAN Expert Working Group for the European Commission, DG XII, Directorate AS-RTD Actions: Strategy and Co-ordination. Brussels, February 1998.

4. 5th Framework: www.cordis.lu/fp5

5. Discussion on 6th Framework: www.cordis.lu/ist/fp6/fpconsult

\title{
Gerontechnology workshop in Japan
}

\author{
Herman Bouma PhD \\ former director of the Institute for Gerontechnology, Eindhoven University of \\ Technology, Eindhoven, the Netherlands. \\ e-mail: heebouma@xs4all.nl
}

\section{Ken Sagawa PhD}

Human Informatics Department, National Institute of Bioscience and

Human-Technology, Tsukuba, Japan.

e-mail: sagawa-k@aist.go.jp

H. Bouma, K. Sagawa, Gerontechnology workshop in Japan, Gerontechnology, 2001; 1(1): 70 - 72. Report on an international workshop Gerontechnology, as held in Tsukuba, Japan, March 2001. The workshop reflects the growing awareness in Japan that technology can contribute toward solving problems related to the aging society. Focus is on technological challenges resulting from aging human perceptual, cognitive, and motor faculties. Remarkable implementations from Japan include efforts by the broadcasting organization NHK to provide all older customers with optimum listening and viewing conditions, and an extensive lifelong-housing program by Seksui. Apart from products and services, a suitable encompassing technological environment is proposed for answering needs of the aging society.

Key words: aging, gerontechnology, Japan, technological environment

\section{INTRODUCTION}

Supported by Japanese ministerial bodies, the National Institute of Bioscience and Human
Technology NIBH organized an international workshop on Gerontechnology in Tsukuba, March 13-16, 2001. 26 Invited speakers 